\title{
Documents Reflecting Current Practices in Library Administration
}

Mr. Rush prepared this paper when he was executive secretary of A.C.R.L. He is now librarian, University of Wyoming.

A ANY of the readers of College and ivi. Research Libraries have helped and will continue to help in a plan to assemble in the office of the executive secretary a collection of significant documents reflecting current practices in the administration of college, university and reference libraries. The plan is a simple one-and I trust that you are sharing in it. If you are not, all you need to do is to place the Headquarters office on your mailing list to receive not only the published materials of your library such as handbooks, personnel codes, annual reports, newssheets, rules and regulations, but also manuscript materials such as budgets and budget justifications, letters and memoranda prepared for policy conferences with library staff and institutional officers and faculty, and memoranda or orders issued to implement policy decisions. Confidential material should be labeled so that it will not be released except by permission of the originating institution.

You may also share in this project from the other end-and a number of you have already done so. The material is here for your consultation. Many of the items have been loaned, and even additional copies have been made of some of the items in order to meet the number of requests.

\section{Annual Reports}

A wide variety of colleges have contributed their annual reports to our col- lection-denominational schools, theological seminaries, technological schools, small private liberal arts colleges, teachers colleges, state colleges and universities, large private universities, and a few junior colleges. Some are printed, sometimes separately with a handsome print job and sometimes incorporated in the president's report; some are mimeographed; and some are carbon copies. A few colleges who are fortunate enough to have been able to maintain files with an extra set of their annual reports for the last few years have sent us sets covering the last eight or Io years. However, most of the reports which we have received cover the last fiscal year. The reports usually review briefly the work of each department through the year, summarize the personnel situation, acknowledge gifts received during the year, include a few statistics, and end by citing the most urgent needs of the library. There is considerable variation in the reports-everything from a simple one-page tabulation presented as the annual report, to long dissertations followed by page after page of elaborate tables. Other points of ten brought into the reports are tributes to retiring staff members, statements of appreciation to the entire library staff, reports on the progress of reclassification programs and of special collections, lists of donors of items to the library, and introduction of new staff members. The particular needs cited in the reports vary from a reference librarian (this school has never had one!) to airconditioning for the rare book room, from a water cooler to a building, from janitor 
service to a modern lighting system. Almost all the reports mention two major difficulties - that of securing trained library personnel on the professional level (apparently the situation in regard to competent clerical help is easing up) and that of space for more books and for larger seating capacity. A usual comment was: we can seat only one eighth, or one tenth, or, in a few instances, one twentieth, of our student body. The only reports that did not mention this problem of space for books and students were those from schools who have a definite building program under way, or at least in the architect-planning stage. In regard to the personnel problem the reports usually attribute this to several factors including an actual shortage of trained librarians and low salary scales which do not recognize the fact that librarians spend as much time acquiring their training as do faculty members. (Incidentally, one report attributed better staff morale to the fact that faculty status had been granted to the professional staff.) Another report felt that improved morale and a greatly decreased staff turnover were directly due to a much-improved salary scale.

\section{Handbooks}

The handbooks which have been received represent every type and size of college or university and are in every conceivable size and shape. Some are leaflets already punched so that they may be kept in a notebook. At least one was designed to fit the inside coat pocket. They vary from a simple mimeographed sheet to an elaborate printed booklet. Some are illustrated with cartoons. Some larger universities issue separate pamphlets for their various departmental libraries. Most handbooks include floor plans of the library, an explanation of the card catalog usually accompanied by illustrations of entries and of properly filled out call slips, an explanation of the classifica- tion system in use in the particular library, a brief review of the use of the main periodical indexes, a list of the library regulations, and a table showing the hours the library is regularly open. Occasional features were a list of aids on theme writing, a short discourse on the parts of a book, examples of correctly stated bibliographies and footnotes. One even included some exercises to be filled in to show that the student understood the text. Another included a bibliography of books on useful study habits! We have also received about a dozen faculty handbooks and a few copies of sheets, forms and reminders sent to the faculty in connection with book buying.

\section{Newsletters, Acquisition Lists, Staff Bulletins}

The newsletters, acquisition lists, and staff bulletins which have reached us appear to be for very much the same purpose, so we will describe them together. We have received these from a good many institutions. They are usually mimeographed or lithoprinted, and run in length from a couple of pages to eight or Io. 'They are issued quarterly, monthly, weekly, biweekly, or "when the occasion seems to call for one." Their purpose seems to be to acquaint library staff members and faculty members with new acquisitions, especially unusual or hard-to-get items; changes in library regulations as to hours of opening, conditions under which books may be borrowed; unusual or special services which the library is prepared to offer; library staff appointments and resignations; the announcement of a new service; notes on subjects of general interest such as the United States Book Exchange or receipts under the Farmington Plan; reports by staff members on library association meetings or institutes attended; descriptions and announcements of exhibits; requests for cooperation in the collection of school 
"ephemera" such as programs, handbills, etc.; staff association news. Some of the acquisition lists are arranged by subject and include the library call numbers. Items occasionally included in the bulletins are such things as an organization chart of the library, an outline of procedure for shifting the public catalog, lists of visitors, descriptions of outstanding gifts to the library, notices of new forms to be put into use, requests for faculty cooperation in book selection procedures, "testimonials" to certain staff members for outstanding work, lists of publications of staff members and/ or of faculty members, notes on microfilm acquisition, publicity for library radio programs, comments on the new library school curriculum leading to a master's degree, and comment on censorship in whatever form it may appear. In some instances they have been used for such purposes as presenting a list of the periodicals and newspapers available in the library, a statement of policy with regard to the collecting of books, a questionnaire on the use to which the bulletin was being put (the next issue of this particular bulletin stated that the response to the questionnaire had been favorable), a complete statement of regulations and policy relating to the professional library staff. One newsletter has carried a series of fascinating letters from a librarian describing his European trip and his endeavors while abroad to secure underground publications and other publications of the war period.

\section{Acquisition Codes}

A few libraries have sent in their acquisition policies and procedures showing sound planning and division of responsibility not only with the departments of the university but with other institutions as well.

\section{Audio-Visual}

A few institutions have sent in their recommendations and policies regarding audio-visual material-their acquisition, housing, use, and production. One college sends its monthly audio-visual bulletin which reviews a few educational films, tells what services are available in its audiovisual bureau and occasionally comments on types of equipment.

\section{Faculty Information}

There seems to be an attempt on the part of many librarians to keep their faculty informed.

I. A number of handbooks specifically for faculty.

2. Statements on reserve shelf procedures, spending of annual book appropriations, book orders, etc.

3. An occasional letter to the faculty.

\section{Library Publications}

A few libraries are making known the wealth of their collections by preparing information about their treasures. This material has been received in book, pamphlet, monograph, periodical and mimeographed form.

\section{Special Surveys and Reports}

Some that have been received are:

I. "A Survey of Photographic Facilities for Library and Scholarly Purposes in California," 1946.

2. "Report on a Survey of the Problems of Using and Producing Microfilm at Louisiana State University," I945.

3. "Library Expansion Preliminary Statement of Needs," 1947.

4. "University of Illinois Library Senate Committee on the Library Report," I946-47.

5. "Northwestern's Report on the Survey of the Rare Book Collection," I948.

6. A Survey of the Libraries of Cornell University, 1948.

7. "The Conservation of Newspaper Resources in California Libraries," I947.

8. "A Survey of the Library of the Armed Forces Staff College at Norfolk, Va.," 1948. 9. A Report on the Mary Reed Library, University of Denver, 1947. 
10. "A Survey of the Library of Northwestern State College, Natchitoches, La.," 1947.

I I. "The Library Building Situation at Louisiana State University," 1947.

12. "Library (building) Additions at University of Illinois," 1948.

13. "A Library Program for the Universidad Nacional Autonoma de Mexico," 1948.

I4. "Appraisal of Stephen F. Austin State College Library According to the Standards of the Southern Association of Colleges and Secondary Schools. . . ," 1947.

15. "Report on Status of the Department of Archives and Manuscripts of Louisiana State University, with Recommendations," I945.

16. "Some Changes in the Organization of the Libraries at Columbia University," 1948.

I7. "Special Report from the Librarian, and the 1948-49 Library Budget Request of the Publications and Library Committee of $\mathrm{Pa}$ cific University," 1948.

I8. "Preliminary Detail of the Development Program for Rensselaer Polytechnic Institute Library," 1947.

19. "Russell Sage College Library Report of Conditions," 1946.

20. "Survey, Summary, and Budget Request for the Upper Iowa University $\mathrm{Li}$ brary," 1947.

21. "A Survey Report of the University of Idaho Library in Relation to Comparable University Libraries," 1948.

22. "Colorado State A \& M College Library Reorganization Proposals," 1942 (and a number of subsequent reports-the latest dated April 1949).

23. "A Constructive Program for the Baker Library of the Harvard Graduate School of Business Administration."

\section{Miscellaneous}

We have received a number of bibliographies-one teachers college got out a monthly bibliography last year listing recent material available in their library, another school issues occasional bibliographies on subjects that are currently in the news. We have also received a few examples of bibliographies prepared in connection with particular courses, such as one of reference materials helpful for graduate students in
English literature, another on hunting lodges, a manual of reference services in education, a selected list of general reference books for college students, general indexes and general bibliographies. A few more elaborate bibliographies covering an entire special collection have also been received.

Several librarians have sent us reports prepared by themselves or by their library building committees summarizing what they believe to be the features most needed in their proposed library buildings. Several colleges and universities have sent us brochures picturing the buildings which they now have under way. And we have received a few pamphlets apparently being distributed to make widely known the particular school's need for a new library building. A few schools have sent us pamphleis issued upon the occasion of the dedication of a new library building.

About a half dozen quite recent staff manuals have been sent, and perhaps a dozen instruction guides or manuals for student assistants in the library.

A number of other items are in the files: perhaps a half dozen organization charts; a few instruction sheets to graduate students and teachers on the possibility of securing interlibrary loans; statements of policy of faculty library committees; a few bulletins directed to organized Friends of the Library groups and some samples of invitations to join the Friends of the $\mathrm{Li}$ brary; policy statements on various subjects such as ownership of books, acceptance of gifts, department and branch libraries, preservation of archives; special reports and self-surveys pointing out particular problems and suggesting means of correcting them, and often suggesting a collecting policy for the school in question; a number of long-term planning and survey reports; a memorandum setting up an inventory committee for the library and giving an 
outline of the steps it should take in setting up inventory procedure; blanks for such things as staff monthly timesheets, and circulation, reference, and fines records; statements of acquisition policies in several libraries; a statement of the cooperative collecting policy between two large libraries located in the same immediate vicinity; the occasional letter to the faculty issued by one librarian; notes on cooperation issued by one of the colleges belonging to a regional committee on cooperation; a few items used in courses instructing students in the use of the library; statements to the faculty on book budget; allotments of library funds; functions of and reports of faculty library committees; inter-office correspondence; salary schedules.

\section{Unusual Items}

Perhaps also it might be of interest to mention a few of the unusual or "different" items that have come in, such as the following:

Northwestern's nine-page mimeographed statement on Opportunities for Giving to the Libraries at Northwestern University; University of Denver's list of Library representatives in faculty departments; Brooklyn College's Open Letter from the Head of the Circulation Division to the Students at the Main Desk; West Virginia Library Association's College Library Newsletter; University of California at Los Angeles' Branch Library Code; Drake's printed list of staff meetings and their topics for the year; University of Arkansas' Searching Manual; and the Massachusetts Institute of Technology's Library Annual.

Some librarians have been most generous, and their efforts in sending this material are appreciated. However, we should like to receive a lot more from most of you. So that you will have a better idea as to what some libraries are sending us, I should like to list here as good examples the items received from two different types of libraries.

Brooklyn College has sent us: annual report of the librarian; library handbook for students; library handbook for the faculty; Recent Accessions and Library News; Audio-Visual Bulletin; Friends of the $\mathrm{Li}$ brary material; bibliographies on 17 different subjects ranging from "What's Wrong with the American Radio" on two mimeographed pages to a 20-page pamphlet on a selected list of general reference books for college students; 38 different printed or mimeographed forms of all types, such as a sheet for the faculty to use when requesting books to go on reserve, instruction to book dealers, statistics report sheets, overdue notices, duplicate order slips, and problems on the use of the library; Function of Departmental Library Committee; information on use of exhibit cases; outline of orientation tour.

Baker Library, Harvard Graduate School of Business Administration, has sent: annual report of the librarian; a guide to Baker Library; The Growth of the Baker Library; The Baker Library as a National Research Institution; A Constructive Program for the Baker Library; List of Business Manuscripts in Baker Library; a classified list of industries; a classified list of the geographical and political divisions of the Earth's surface; Adam Smith and the "Wealth of Nations"; 'The Business School Library and Its Setting; Baker Library Graduate School of Business Administration Reference Lists; Business Biographies and Company Histories; The Kress Library of Business and Economics; The Vanderblue Memorial Collection of Smithiana; The Pioneer Period of European Railroads; An Essay on the Proper Method for Forming the Man of Business: 1716; The Kress Library of Business and Economics Catalogue. 